\title{
3rd ICTs and Society Meeting; Paper Session - Inequalities: social, economic, political; Paper 3: Internet in China: Myths and Realities
}

\author{
Robert M. Bichler \& Eva Gaderer
}

UTI - Unified Theory of Information Research Group, [www.uti.at], robert.bichler@uti.at University of Salzburg, eva.gaderer@gmx.at

The People's Republic of China, with an estimated total population going beyond 1.3 billions, is one of the fastest growing telecommunication markets in the world. In June 2010 the Information Office of the State Council of the People's Republic of China published a white paper on the Internet situation in China stating that by the end of 2009 the number of Internet users reached 384 million, which was 618 times that of 1997, with an annual increase of 31.95 million users. Following the white paper, the total number of Internet users in China exceeds the number of users in the European Union, which is estimated to be 319.393 .400 (Internet World Stats, 2010, online). There is no doubt that China is becoming a new super-power in various ways, including the IT sector. The white paper clearly highlights this by stating: "The Chinese government energetically advocates and actively supports the development and application of the Internet across the country. [...] China now boasts the most Internet users in the world." (Information Office of the State Council of the People's Republic of China, 2010, online)

Although China is becoming a central player in the offline- and online world, there are still many misconceptions, especially in the West, about the way ICTs are implemented and used in the country. This contribution should help to shed more light on current developments taking place in the rapidly changing Chinese (new) media landscape by contrasting some myths with realities. We argue that the use of ICTs is a cultural practise, which is constantly shaped and re-shaped by the existing political, economical, ecological and technological circumstances in a given society, with the economic conditions being dominant. These framework conditions are again influenced by globalisation processes and therefore it is getting more and more obsolete to speak of unique cultural groups. A prominent advocate for a clear-cut pattern across cultures is Geert Hofstede. He argues that there are four central and 'largely independent' (1983, p. 78) bi-polar dimensions of a national culture. The dimension 'Individualism versus Collectivism', which describes the extent to which individuals are integrated into groups (Hofstede, 1991, p. 51; Hofstede \& Peterson, 2000, p. 401) is used quite often to differentiate communication styles and strategies of various ethnic groups (Burleson \& Mortenson, 2003; Seo, Miller, Schmidt \& Sowa, 2008). Therefore Wang and Chen (2010, p. 1) mention that "[...] Chinese and East Asians have often been chosen to represent the typical collectivist cultural group to contrast with Americans as the typical individualist cultural group. Likewise, the communication style that has reportedly characterized collectivistic cultures is also found to represent the features of Chinese and East Asian people". For example, people in collectivist, East Asian cultures such as Korea and Japan tend to be indirect, no-expressive, and high context, while those in individualist cultures such as the United States and Australia are direct, expressive, and low context (Gudykunst et al., 1996). Chen and Starosta (1997, p. 5) stress that in China „the purpose of human communication is to develop and 
keep a harmonious relationship in a continuously transforming process of mutual dependency among interactants" and therefore "harmony is the end rather than the means of human communication".

As a consequence, Chinese people in general prefer to use "softer" communication strategies, including encouragement, creditgiving and example-setting, while attempting to gain influence (Ma \& Chuang, 2001). In conflict situations Chinese rely more on unofficial mediation to resolve the issue ( $\mathrm{Yu}$, 1997).

Globalisation has a very strong impact on contemporary societies and therefore such clear distinctions are oversimplifying. Triandis (1994, p. 42) for example states, "[...] the two can coexist and are simply emphasised more or less [...] depending on the situation. All of us carry both individualist and collectivist tendencies". Instead of framing cultures into allexplaining categories in order to describe communication processes, it seems to be more appropriate to lay the focus on the current economic system and its impact on the other spheres of society. Contemporary societies, including the Chinese society, are capitalistic societies where human acting is always influenced by the economy. Or, as Hardt and Negri $(2004$, p. 101) phrase it: „As the impersonal rule of capital extends throughout society well beyond the factory walls and geographically throughout the globe, capitalist command tends to become a ,non-place' or, really, an every place." This process not only strongly affects politics, but also individual and societal norms, rules and values. The expansion of capitalistic logic into everyday life was described by Habermas as a colonialization process in which instrumental rationality spills from the economic sub-system over to other areas of life and "achieves dominance there at the expense of moral-practical and aesthetical-practical rationality" (Habermas, 1987, p. 304).

In our opinion such an approach offers the potential to gain much more sophisticated insights into communication behaviours. For example in China it seems that societal stability is a primary goal of the Chinese government in order to ensure economic growth. "The totalitarian socialist state that Mao had built is no more. In its place is a more cynical, stable, and nimble bureaucracy, one that values self preservation above all else and relies on an often corrupt and predatory form of capitalism to survive" (Pan, 2008, p. xvi). This aim coincides with the interests of a large number of Chinese citizens, which are better educated and more prosperous than at any time in Chinese history. "By almost any measure, the country's last twenty-five years have been the best in its five-thousand-year history" (Pan, 2008, p. v). Individual media practices are based on worldviews and therefore censorship of the media, especially the Internet, is widely tolerated, if not favoured. Censorship is thus not considered to be a bad thing; in contrary it is often seen as a necessity, which concurs with colonized individual norms and values. Hachten (2010, p. 26) argues that due to the extraordinary economic growth, the Chinese people hold strictly positive views of their national economy and the direction their country is taking. Scotton and Hachten go even one step further when they argue that the Chinese economic success goes hand in hand with a fierce nationalism and that "most urban Chinese are proud of their new China and deeply resent criticism from abroad" (Scotton \& Hachten, 2010, p. 3). We think that the media in China, the same applies for other developing regions, should not be measured by Western standards. The emphasis should be on the given individual media practices, which are highly determinated by the prevailing economic system.

\section{Myth and Reality I}

China is considered to be Communist country and as history has shown, this goes along with censorship and suppression of freedom of speech. Therefore in China no objective media coverage and no uncensored information exist. It is believed that only capitalisms can pave the way for democracy, or as described by Philip Pan in his book Out of Mao's Shadow: "The West has assumed that capitalism must lead to democracy, that free markets inevitably result in free societies. But by embracing market reforms while continuing to restrict political freedom, China's Communist leaders have presided over an economic revolution without surrendering power. Pros- 
perity allowed the government to reinvent itself, to win friends and buy allies, and to forestall demands for democratic change" (Pan, 2008, p. xiv).

Thus contemporary Chinese society is better referred to be postsocialism or postTiananmen. Postsocialism can be differentiated as a label of historical periodization, as a structure of feelings, as a set of aesthetic practices and as a regime of political economy (Zhang, 2007, p. 50). Authoritarian capitalism or socialist market economy as Deng Xiaoping called it, is forced by economic interests which go hand in hand with a connection to the global network infrastructure. Therefore information flows into China in ways never imagined by the leading Communist Party and the Authoritarian Media Theory is not capable of explaining the current situation. The fast distribution of information from abroad and within the country is characterised by two simultaneously happening developments: widespread Internet adoption and the diffusion of mobile communication in all parts of the country. The Chinese citizens hence "[...] enjoy greater prosperity but also greater personal freedom and access to information than ever before under Communist rule" (Pan, 2008, p. v).

The usage of mobile technologies makes it more difficult for authorities to monitor the distributed content. Twitter and Flickr for example were shut down shortly before the Tiananmen anniversary, but discussions spread over alternative channels. The same thing occurred during the Sichuan earthquake, neglecting governmental orders, news were spread over China through cell phones and the Internet before the Ministry of Information could react (Scotton, 2010, p. 35). It is almost impossible for the Chinese government to monitor all cell phone communication. Especially for the young urban generation, cell phones and the bi-directional way of communication are omnipresent (Scotton, 2010, p. 36 ). But it lies in the hands of every individual if methods to by-pass Chinese censorship are used to get access to e.g. Facebook or to participate politically and mobilize people for protest.

\section{Myth and Reality II}

The so-called 'Great firewall of China' is considered to be partly a very effective tool to keep unwanted material out of China. The implementation of the monitoring system is from a technological point of view quite simple, due to the fact that all traffic is lead through the state controlled network. But this wall often seems to be more like a fence. Although the Chinese government censors numerous websites and applications, major international news sites (e.g.: New York Times, Le Monde, Die Zeit, etc.) are freely accessible. Furthermore technical solutions to by-pass censorship are widespread and easily available by using international proxy servers (Scotton, 2010, pp. 30f). Even though Facebook is blocked in China there exists an EXPO 2010 group that offers a manual and a link to a Chinese website where one can download the necessary application for free. Although it is quite simple to get full access to the Internet, our impression is that most Chinese citizens are only concerned about Chinese websites and Internet applications and therefore the traffic on foreign sites can be considered marginal. Liang Guo supports this assessment by concluding in a study taken out by the Center for Social Development at the Chinese Academy of Social Sciences that the preferred websites are all Chinese (Guo, 2007, p. 45).

It seems that the Chinese government is mainly concerned about so called Web 2.0 applications. Within recent years Web 2.0 gained more popularity in China. The estimated number of bloggers in China is considered to be around 500.000 , but counting the people using social network sites obviously seems to be impossible (Scotton, 2010, p. 28). Clearly a huge amount of content is produced through this blogging-scene, what makes it almost impossible for governmental authorities to monitor all discussed topics. If 'sensitive content' is discovered, it will be deleted effectively. Furthermore a new regulation asks users to provide their ID in order to create a new account. The definition of sensitive content by governmental authorities includes politics and pornography, but there is no clear policy what exactly (besides the three $\mathrm{T}$ ) is allowed and what is not acceptable. The three $\mathrm{T}$ refer to Tibet, Tiananmen and Taiwan, 
which are considered to be sensitive topics and therefore are mostly not discussed in public. Also, concerning gambling addiction, several providers of online gaming and Internet cafes were shut down. Monitoring activities in China are carried out by the Ministry of Information Industry (MII), China Internet Network Information Center (CNNIC) and the State Council Information Office (SCIO). Together they run approximately 30.000-50.000 monitors to surveillance online content (Scotton, 2010, pp. 29f). Youtube, Facebook, Blogger, Twitter, just to mention a few, are all blocked in China, but for almost all services there exists a Chinese counterpart. Parallel to the Internet, there has been a huge Chinese telecommunication system established, offering the same variety of services and products as in the Western world, with the advantage that they are optimised for Chinese users.

\section{Myth and Reality III}

Networking via the Internet plays a significant role for governmental actors in China. The main goal is to gain public attention and change behaviours. Involvement of the public in their activities is not really the aim of the Chinese government. But on the one hand in time of crisis they need support to legitimise their work and on the other hand a broader public is necessary to gain attention. In 2008 global discussed public events like the protests in Tibet, the Sichuan earthquake and the Beijing Olympics brought new challenges for the Chinese government. During the protests and riots in Tibet in March 2008 they focussed on a restrictive media policy, for example not allowing foreign journalists to enter the region and continuously blaming Western media for misinterpreting the Tibetan situation. "Playing to national pride and national insecurity, the party used censorship and propaganda to position itself as defender of the motherland and at the same time block any examination of Tibetan grievances or its own performance in the crisis" (Hachten \& Scotton, 2010, p. 11). Whereas the reaction of the Chinese government on this event could be defined as political propaganda via the media to enforce public nationalism, in other incidents that occurred in 2008 it seems that they changed their strategies from propaganda towards public re- lations. Two months later after the earthquake in the Sichuan province, for example, the Chinese government had to open up their media policy due to pressure of media companies, journalists and bloggers. Within one day, the restrictive strategy of not publishing details about the earthquake was withdrawn and instead a public relations campaign on the quick and effective rescue efforts of the government in the region was introduced online and offline. The Olympic Games in Beijing later in 2008 function as an example of overwhelming strategies to enforce positive reports about China. The aim of the Central Propaganda department was to transport a positive picture of China all over the world, using political public relations. Clumsy propaganda is more and more replaced by elaborated public relations strategies by means of Internet technologies, which simulate the involvement of citizens, an open decision-making process and unrestricted access to information. Yin (2010, p. 152) points out that there "has been a pervasive spread of Western-style public relations among governmental entities as part of their political strategies". This appraisal is supported by the findings from a survey among Chinese governmental officials conducted by $\mathrm{Ni}$ Chen. She states that the Chinese government is "[...] beginning to abandon its old propaganda schemes, and adopting government PR measures to promote itself" (Chen, 2003 quoted in Yin, 2010, p. 152). Yin (2010, p. 153) concludes that the "[...] overall goals of China's public relations programs are to obtain public support and to advance political and commercial interests at home and abroad".

\section{Resulting key issues and challenges for ICTs and Societies research}

Existing theoretical and empirical approaches to study 'ICTs and Societies' are often not capable of explaining current developments, especially outside the Western world. To study the political organisation of media systems for example the 'Four Theories of the Press' (Siebert, Peterson \& Schramm, 1963) expanded by the Developmental Theory often serve as a starting point. The Authoritarian Media Theory seemed to be appropriate for describing the media land- 
scape in China until the 1990s, but with the rise of Internet technologies it is getting more and more useless. There is an urgent need to create new models, which can explain the ongoing transitions, not only in China, but also throughout the developing world. The aim of such new approaches should be to incorporate cultural differences, not limited to the use of technologies, but also including discrepancies in political realities and individual worldviews with an emphasis on economic conditions.

Hand in hand with the theoretical problems resulting out of the ongoing transitions proc- esses empirical challenges occur: How to conduct research in countries where the access to field works, e.g. due to political constrains, is not given? How to handle statistical data provided by central governmental agencies, which possible pursue objectives in a variety of fields, not necessarily focused purely on scientific evidence? How should researchers deal with cultural extraneousness? This list of exemplarily questions is not comprehensive, it rather illustrates the complexity of the topic and the challenges 'New Media and Societies' research is facing today.

\section{References}

Burleson, B.R., \& Mortenson, S.R. (2003). Explaining cultural differences in evaluations of emotional support behaviours: Exploring the mediating influences of value systems and interaction goals. Communication Research, 30(2), 113 146.

Chen, N. (2003). From Propaganda to Public Relations: Evolutionary Change in the Chinese Government. Asian Journal of Communication, 13(12), 96-121.

Chen, G.M. \& Starosta W.J. (1997). Chinese Conflict Management and Resolution: Overview and Implications. Intercultural Communication Studies 7, 1-17.

Gudykunst, W.B., Matsumoto, Y., Ting-Toomey, S., Nishida, T., Kim, K., \& Heyman, S. (1996). The influence of cultural individualism-collectivism, self-construals, and individual values on communication styles across cultures. Human Communication Research, 22 (4), 510-543.

Guo, L. (2007). China Internet Project Survey Report 2007. Surveying Internet Usage and its Impact in Seven Chinese Cities. Research Center for Social Development, Chinese Academy of Social Sciences. Retrieved June 01, 2010 from http://www.markle.org/markle_programs/project_archives/2001/chineseacademy.php

Habermas, J. (1987). The Theory of Communicative Action: the Critique of Functionalist Reason (Vol. 2). Cambridge: Polity Press.

Hachten, W. A. (2010). Development and Theory of the Media. In J. F. Scotton \& W. A. Hachten (Eds.) New media for a new China (pp. 19-27). Wiley-Blackwell: UK.

Hachten, W. A. \& Scotton, J. F. (2010). 2008: New Challenges to China's Media. In J. F. Scotton \& W. A. Hachten (Eds.) New media for a new China (pp. 11-18). Wiley-Blackwell: UK.

Hardt, M. \& Negri, A. (2004). Multitude. War and Democracy in the Age of Empire. New York: Penguine Books.

Hofstede, G. (1983). The cultural relativity of organizational practices and theories, Journal of International Business Studies, 14 (2), 75-90.

Hofstede, G. (1991). Cultures and organizations: Software of the mind. London: McGraw-Hill.

Hofstede, G. \& Peterson, M.F. (2000). National values and organizational practices. In N.M. Ashkanasy, C.P.M. Wilderom \& M.F. Peterson (Eds.), Handbook of organizational culture and climate (pp. 401-405). London: Sage.

Internet World Stats (2010). Internet Usage in European Union. Retrieved June 01, 2010 from http://www.internetworldstats.com/stats9.htm

Information Office of the State Council of the People's Republic of China (2010). White Paper: The Internet in China. Retrieved June 01, 2010 from http://english.gov.cn/2010-06/08/content_1622956.htm

Ma, R. \& Chuang, R. (2001). Persuasion strategies of Chinese college students in interpersonal contexts. Southern Communication Journal, 66 (4), $267-278$.

Pan, Ph. P. (2008). Out of Mao's shadow: the struggle for the soul of a new China. New York: Simon \& Schuster.

Scotton, J. F. (2010). The Impact of New Media. In J. F. Scotton \& W. A. Hachten (Eds.), New media for a new China (pp.28-43). UK: Wiley-Blackwell.

Scotton, J. F. \& Hachten, W. A. (2010). Introduction. In J. F. Scotton \& W. A. Hachten (Eds.) New media for a new China (pp. 1-10). Wiley-Blackwell: UK.

Seo, K.K., Miller, P.C., Schmidt, C., \& Sowa, P. (2008). Creating synergy between collectivism and individualism in cyberspace: A comparison of online communication patterns between Hong Kong and U.S. students. Journal of Intercultural Communication, 18. Retrieved June 1, 2010 from http://immi.se/intercultural/nr18/kay.htm 
Siebert, F. S., Peterson, T., Schramm, W. (1963). Four theories of the press: The authoritarian, libertarian, social responsibility and Soviet communist concepts of what the press should be and do. Urbana, Chicago: University of Illinois Press.

Triandis, H.C. (1994). Individualism \& collectivism. Boulder, CO: Westview Press.

Wang, G. \& Chen Y.K. (2010). Collectivism, relations, and Chinese communication. Chinese Journal of Communication, 3 (1), 1-9.

Yan, J. (2010). Public Relations. In J. F. Scotton \& W. A. Hachten (Eds.) New media for a new China (pp. 141-162). WileyBlackwell: UK.

Yu, X. (1997). The Chinese native perspective on Mao-dun (conflict) and Mao-dun resolution strategies: A qualitative investigation, Intercultural Communication Studies, 7. Retrieved June 1, 2010 from www.trinity.edu/org/ics/ICS\%20lssues/ICS\%20VII/ICS-VII-1-Yu.pdf

Zhang, Y. (2007). Rebel without a cause? China's New Urban Generation and Postsocialist Filmmaking. In Zhang Zhen (Eds.), The urban generation. Chinese Cinema and Society at the Turn of the Twentyfirst Century (pp. 49-81). Durham and London: Duke University Press.

\section{About the Authors}

Robert M. Bichler

Robert M. Bichler is lecturer at the Shanghai International Studies University (SISU) and member of the Unified Theory of Information (UTI) Research Group - Association for the Advancement of Information Sciences. Prior he was a research fellow and lecturer at the ICT\&S Center at the University of Salzburg. Address: Shanghai International Studies University, German Department, 550 Da Lian Road (W), Shanghai 200083, P.R. China. [email: robert.bichler@uti.at]]

\section{Eva Gaderer}

Eva Gaderer holds a Bachelor degree in Communication Studies, majoring in media economics and international communication at the University of Salzburg. Presently she is working on her master's thesis on strategies and actors in development politics in Nicaragua with a special consideration of the role of (new) media. Currently she is studying in the School of Journalism at the Fudan University in Shanghai as a participant in the Master Exchange Program Media and Communication Management (MCM). [email: eva.gaderer@gmx.at] 